\title{
THE TEMPORARY USE OF AGRICULTURAL LAND - SPECIFIC INSTRUMENT IN AGRICULTURAL EVENTS
}

\author{
G. Velkovska* \\ Faculty of Economics, Trakia University, Stara Zagora, Bulgaria
}

\begin{abstract}
Under the terms of Article 56 (1) of the Rules for the Application of the Law on the Conservation of Agricultural Land [www.lex.bg] in the construction of sites - public property of the state or municipalities, it is possible to use land for a certain period outside the site (track) of the site.

In such cases, land that is needed temporarily in the construction of underground and aerial linear objects is needed and is necessary for geological and other research.

The text of Art. 57, par. 1, 3 and 4 of the aforementioned Rules regulates the relations between the investor of the site and the owner of the land - for the use of the land a contract is signed between the investor of the site and the owner of the land.

The contract is concluded in the presence of an established site (track, terrain) for the site with a decision of the commission under Art. 17, para. 1 Agricultural Land Protection Act [www.lex.bg].

The agreement between the parties sets out the terms and conditions for the use of the land, the amount of the rent, the damages and lost profits, the manner of their payment and the corresponding penalties.

The contract can not be concluded for more than 10 years.

What are the obligations of the investor?

The investor of each site, according to the norm of art. 58 of the Regulation for the application of the law on the preservation of agricultural lands, shall be obliged to return the used temporary land after expiration of the term of the contract in the original form or in a form suitable for agricultural use.

The land shall be brought into this type by the investor on the site at his expense within the term of the contract.

When the use of the land necessitates the construction of buildings and / or facilities of a permanent character, the investor of the site is obliged, within the term of the contract, to propose a change of the purpose of the necessary land after acquisition of ownership or right to build .

In connection with the above, the subject of the article is precisely the basic legal details of the agricultural legislation of the Republic of Bulgaria dealing with the conditions and the process of granting and temporary use of agricultural land in conducting spatial events on it.

The subject of an analysis based on the current legal issue is some of its imperfections, affecting to some extent the negative impact on the effective use of this instrument and worsening the expected results.

The methodology of the SWOT analysis will be used for the analysis needs.

The purpose of the study is to examine and analyze the legal matter of the field of agricultural land use, to summarize and formulate some directions of improvement of the legal framework that it needs in order to fully fulfill its role as a specific and necessary instrument in agro-development activities.
\end{abstract}

Key words: investor, owner, contract, rules, law, right to build, buildings, object

\section{INTRODUCTION}

The agricultural lands, according to the text of Article 2, paragraph 1 of the Law for the Protection of Agricultural Land [www.lex.bg], are qualified as national treasures.

\footnotetext{
*Correspondence to: Gena Velkovska, Trakia University, Faculty of Economics - Stara Zagora city, Bulgaria,e-mail: gvelkovski@abv.bg
}

The use of agricultural land in this aspect is for agricultural purposes only.

The satisfaction of some needs of agricultural infrastructure and other non-agricultural needs is the reason for carrying out preparatory and actual construction procedures to meet these needs, by building up of objects with the appropriate purpose. 
From the point of view of ensuring the implementation of the organizing events with the necessary for their realization area, the temporary use of the agricultural land is a necessary instrument and an adjoining legal regulated process in the structural policy of the agrarian sector.

In connection with the above, the subject of the article is precisely the basic legal details of the agricultural legislation of the Republic of Bulgaria dealing with the conditions and the process of granting and temporary use of agricultural land in conducting spatial events on it.

The subject of an analysis based on the current legal issue is some of its imperfections, affecting to some extent the negative impact on the effective use of this instrument and worsening the expected results.

The methodology of the SWOT analysis will be used for the analysis needs.

The purpose of the study is to examine and analyze the legal matter of the field of agricultural land use, to summarize and formulate some directions of improvement of the legal framework that it needs in order to fully fulfill its role as a specific and necessary instrument in agro-development activities.

\section{Legal conditions for temporary use of agricultural land.}

The construction of sites on agricultural land is associated in certain cases with the need to use agricultural land outside the sites and the routes of the sites.

The norm of art. 56, para 1 of the Regulation for the implementation of the Law for the protection of agricultural lands [www.lex.bg], regulates and approves the legal possibility for using such agricultural land, but for a certain period of time. The other specific legal feature that these lands must possess is their necessity, namely:

First, for land use, land may be provided for the construction of underground and aerial linear objects.

For the purposes of paragraph 2 of paragraph 1 of the Additional Provisions of the Law on the Conservation of Agricultural Land [www.lex.bg], linear objects are motorways, roads, railways, floating, irrigation and drainage channels, underground and
VELKOVSKA G.

overground heat pipes, steam lines, gas pipelines, sewers, cables, power lines, rope, telephone, telegraph, radiocommunication and telecommunication lines;

Second, such lands must be necessary for geological and other research.

The presence of these characteristics, in their proper conditions, gives the investor an opportunity to enter into a contract with the owner of the land.

Except in the above-mentioned conditions, the contract is also concluded under two more conditions, which are reflected in the text of Article 57, paragraph 1 of the Rules for the Application of the Law for the Conservation of Agricultural Land [www.lex.bg]:

In order to conclude a contract for temporary use of agricultural land, there must already be an established site (track, terrain) for the site. The approval of the site for the site must be carried out by the committees under Art. 17, para. 1 of the Agricultural Land Conservation Act [www.lex.bg].

Within the meaning of Article 17, paragraph 1, point 1 of the Agricultural Land Protection Act [www.lex.bg], this is a commission to the Regional Directorate "Agriculture" where the requested area for changing the use of the agricultural land for non-agricultural purposes is up to 50 decares from the fifth to the tenth category or irrigated and the land is in the settlements of the settlements of the respective area.

For the purposes of paragraph 10 of paragraph 1 of the Supplementary Provisions of the Agricultural Land Conservation Act [www.lex.bg], "irrigated" shall be agricultural land which is located in an area served by an irrigation system or irrigation field or it can be irrigated by natural water source, allowing gravitational water supply into the property.

For the other cases, within the meaning of Article 17, paragraph 1, item 2 of the Agricultural Land Conservation Act [www.lex.bg], these functions are assigned to the Agricultural Land Commission of the Ministry of Agriculture, Food and Forestry.

According to the text of art. 40, para 1, item 1 of the Agricultural Land Protection Act [www.lex.bg], the Agricultural Land Commission, by its decision, shall authorize 
the temporary use of agricultural land under the conditions and by the order of the Regulation for the implementation of the Law for the Protection of Agricultural Land lands [www.lex.bg].

\section{Legal Specifics of the Contract for} the Temporary Use of Agricultural Land.

As already noted, parties to a contract for use of agricultural land within a certain period are the investor of the site and the owner of the land that owns it for use.

The main accents in such a contract, according to the norm of art. 51, par. 4 of the Regulations for the implementation of the law on protection of agricultural lands [www.lex.bg] are:

a / the conditions under which agricultural land will be used;

$\mathrm{b} /$ the amount of the rent the investor will pay to the owner;

$\mathrm{c} /$ the time limit for the temporary use of agricultural land which may not be longer than 10 years;

A ten-year period of land use is also introduced for legal and natural persons who build their own facilities. This period applies, except in the cases mentioned, as well as for movable objects that are not permanently connected to the terrain.

The temporary utilization of the agricultural land in these cases shall be permitted by a decision of the commission under art. 17, para 1, item 1 of the Agricultural Land Conservation Act [www.lex.bg] - commission of the Regional Directorate "Agriculture".

When building objects - public ownership of the state and the municipalities, the temporary use of the agricultural land is permitted by a decision of the commission under Article 17, paragraph 1, item 2 of the Agricultural Land Protection Act [www.lex.bg] - the Agricultural Land Commission at the Ministry of Agriculture agriculture, food and forestry.

d / damages and lost profits, the manner of payment and the corresponding penalties.

The main obligation of the investor is to return the agricultural land in its original form or in a form which is suitable for agricultural use after expiration of the agreed term.

Aligning the agricultural land in this kind is a commitment of the investor.
The investor also takes all the costs for this purpose.

In the norm of art. 58, par. 3 of the Rules for Implementation of the Act on Conservation of Agricultural Land [www.lex.bg], another investor's commitment has been confirmed. It is related to the emerging need for construction of buildings and / or facilities of a permanent nature within a term agreed for temporary use.

In such a situation, the investor is obliged, within the term of the contract, to propose a change in the designation of the necessary land after acquiring on it:

- right to property;

- right to build.

Failure to comply with the time limit for returning the farmland agreed on a temporary basis by the investor is the legal basis for the investor to impose sanctions.

The sanctioning of the investor shall be carried out on the basis of Art. 41, para 1, item 1 of the Law for Protection of Agricultural Lands [www.lex.bg].

The legal argument in this case is related to violations ascertained as a result of activity that caused damages, contamination and destruction of the agricultural land provided for temporary use and according to the text of item 6 and if the investor does not release in due time the provision granted temporarily using agricultural land or not returning the agricultural land in its original form.

In addition, the investor sets a time limit for returning and restoring farmland.

Others, provided for in the norm of Art. 59 of the Regulations for the Application of the Law for the Conservation of Agricultural Lands [www.lex.bg], shall be imposed in the following cases:

a / when the agricultural land is threatened and it is practically impossible to use this land for agricultural purposes and the site built by the investor is public municipal property,

b / when the agricultural land is in the first case, the investor is sanctioned according to Art. 41, para 1, item 2 of the Law for the Protection of Agricultural Lands [www.lex.bg].

The text of Art. 41, para 1, regulating the amount of the fine in the range from BGN 500 
to 5000 per person, which, according to the text of item 2, uses the agricultural land for non-agricultural purposes without permission to change its purpose.

The investor is also required to propose a change in the purpose of the land and to pay the corresponding fee in double amount irrespective of any other indemnities which are due to the owner of the agricultural land.

In the latter case, besides sanctions, the investor has another obligation - to restore the agricultural land in its original form.

\section{Analysis of some imperfections in agricultural legislation dealing with the use of agricultural land temporarily.}

From the legal specificities of the land-use institute, discussed and discussed here, can use the SWOT method to group and highlight the strengths and weaknesses of the legal matter and on this basis the respective opportunities and threats.

A / Strengths:

a / the main strength, as we have already pointed out, is the normative focus in the purpose of the temporary use of agricultural land as a specific and necessary instrument for conducting spatial events on agricultural lands;

$\mathrm{b} /$ Another strong party is the granting of the legal privilege to any investor who, acting as an active subject in organizational events on agricultural land, can, without any obstacles and legally, carry out the planning activities over time;

c / the third strong country is the legally regulated role of the state agrarian management, through the two commissions under art. 17, para 1 of The Law on the Conservation of Agricultural Land [www.lex.bg] at the entrance of the technological cycle for temporary use of agricultural land.

B / Weaknesses resulting from some regulatory imperfections:

a / one of the weaknesses, is the maximum ten-year limit for the temporary use of agricultural land.

From the position of the postulate on the main purpose of agricultural land, this period actually creates opportunities not only for the deterioration of the mentioned postulate, but also for the reduction of usable agricultural land in real terms.
If we use as an analogue some norms of the spatial planning legislation, and rather the Spatial Development Act [www.lex.bg], the ten-year term can be qualified as a hidden possibility to postpone spatial planning over time by extending the term for a building permit;

b / As another weaker country, the stipulated conditions for the location of movable objects can be specified within the 10-year period.

Given that movable objects are subject to a specific legal regime, it is in the absence of legal logic that such sites be located on agricultural land within ten years and thus impede the use of agricultural land for agricultural purposes;

c / the third weakness of the legal framework are the pre-set, albeit not official, legal possibilities for the sanctions to be sanctioned by the investor, which violations are usually found after post-factum - for example, construction on the agricultural land of another owner without changing the its purpose.

$\mathrm{C} /$ The strengths and weaknesses of the legal framework are prerequisites for providing opportunities, but also for threats.

The main possibility, as we have already mentioned, is the opportunity offered to the investor to be able to carry out the development activities on the respective agricultural territory in accordance with the legal regulations and in concrete terms on the basis of the terms of a contract concluded between the landowner and it for temporary use of certain agricultural land.

The underlying threat is rooted in the ten-year period in which, in the absence of specific legal bargaining, the investor may, in addition to changing the designation of agricultural land, may impair its qualities.

\section{Conclusion}

The review of the legal framework concerning the temporary use of agricultural land for the purposes of the agro-planning measures leads to the following conclusions, mainly concerning the necessity to improve and develop the legal matter in the following directions:

First, shortening the time-limit for the use of agricultural land - up to a maximum of three years; 
Second, by subordinate act of specific accents for current, preventive and final control by the commissions under art. 17, para 1 and of their joint actions with the bodies of The Ministry of Environment and Water and the National Construction Control Directorate [www.lex.bg];

Thirdly, regulation of specific arrangements for the placement of removable objects on agricultural land for temporary use for a period of no more than one year;

Fourth, specifying the amount of criminal sanctions for the investor in a more differentiated aspect and according to the severity of the infringement.

These and other changes and additions would help strengthen the role of temporary use of agricultural land as a specific instrument in agricultural events on agricultural land.

\section{REFERENCES}

1. Law on protection of agricultural lands, changed SG. issue 35 of 24 April 1996, amend. and completed SG. No. 83 of October 9, 2018;

2. Rules for Implementation of the Law for Conservation of Agricultural Lands, adopted by Decree of the Council of Ministers No 240 of 24.09.1996, SG. No. 84 of 4 October 1996, amend. and completed SG. No. 93 of November 9, 2018;

3. The Spatial Development Act, in force since March 31, 2001, SG. issue 1 of 2 January 2001, amend. and completed SG. issue 41 of 21 May 2019, supplemented. SG. No. 44 of June 4, 2019;

4. www.lex.bg. 